\title{
Review on carbon capture and storage for construction engineering.
}

\section{Revisión sobre captura y almacenamiento de carbono para ingeniería de la construcción.}

\author{
Yedulakshmi Nair ${ }^{1}$, Elba Helen George ${ }^{2}$ \\ ${ }^{1}$ PG Student, Department of Civil Engineering, Toc H Institute of Science and Technology, \\ Arakkunnam (Kerala), India \\ ${ }^{2}$ Assistant Professor, Department of Civil Engineering, Toc $\mathrm{H}$ Institute of Science and \\ Technology, Arakkunnam (Kerala), India \\ email(1): yedulakshminair@gmail.com,email(2): elbaheleng@tistcochin.edu.in
}

\section{ABSTRACT}

Global warming and climatic changes due to pollution have triggered the global efforts to reduce the concentration of atmospheric carbon dioxide. The carbon dioxide capture and storage method is considered as a strategy or plan of action for meeting carbon dioxide emission reduction targets. This paper aims at providing an intensive review of various carbon capture and storage techniques, transportation of carbon dioxide $\&$ the utilization of this captured carbon dioxide in the construction industry. It also provides a huge perception of the manufacturing process of various construction materials using carbon dioxide. This review may present a clear understanding of the carbon upcycling technologies \& everything we do is geared towards a goal of creating a circular economy $\&$ awaken new ideas to promote its practical application in construction materials.

Keywords: Carbon abatement technology, Carbon capture, Carbon storage, Carbon transportation, Safety and tracking.

\section{RESUMEN}

El calentamiento global y los cambios climáticos debidos a la contaminación han desencadenado los esfuerzos globales para reducir la concentración de dióxido de carbono atmosférico. El método de captura y almacenamiento de dióxido de carbono se considera una estrategia o plan de acción para alcanzar los objetivos de reducción de emisiones de dióxido de carbono. Este documento tiene como objetivo proporcionar una revisión intensiva de diversas técnicas de captura y almacenamiento de carbono, transporte de dióxido de carbono y la utilización de este dióxido de carbono capturado 
Sustainability, Agri, Food and Environmental Research, (ISSN: 0719-3726), 10(X), 2022: http://dx.doi.org/

en la industria de la construcción. También proporciona una gran percepción del proceso de fabricación de varios materiales de construcción que utilizan dióxido de carbono. Esta revisión puede presentar una comprensión clara de las tecnologías de reciclaje de carbono y todo lo que hacemos está orientado hacia el objetivo de crear una economía circular y despertar nuevas ideas para promover su aplicación práctica en materiales de construcción.

Palabras clave: tecnología de reducción de carbono, captura de carbono, almacenamiento de carbono, transporte de carbono, seguridad y seguimiento.

\section{INTRODUCTION}

Carbon capture and storage (CCS)/Carbon seize and garage is the remediation measure that assist to lessen the $\mathrm{CO}_{2}$ emissions in the energy, and other intensive sectors (cement, petrochemical, metallurgy). CCS technology includes carbon dioxide capturing from numerous industries power plants and from the ecosystem through Direct air capture, post-combustion, pre-combustion, oxy-fuel combustion and which is then properly transported via pipelines, ships, motor transport and injected to the proper storing region for an extended period in the ground, ocean or as a mineral carbonate, geological formations such as depleted oil and gas reservoirs, coal bed formations and deep saline aquifers. Ocean storage relies on the principle that the ocean bed has an excessive capability to keep the $\mathrm{CO}_{2}$ at more depth.

Every concept begins off with a problem. Ours turned into: take the waste of these days and use it to construct a better tomorrow for our future generation by recycling. We have created flexible and high-efficiency solutions to carbon usage which has made sustainability easy and can be implemented today making an enormous impact on this earth. The carbon dioxide can be utilized: to make carbon nanotubes, carbon fiber, biofuels from micro algae, Mineral carbonation, in concrete building materials to make chemical compounds and bioplastics, to make green materials, dry ice pellets to dispose of paints. Other than manufacturing, $\mathrm{CO}_{2}$ also can be applied in the $\mathrm{CO}_{2}$ sand casting process, oil recuperation system, in portable pressure tools, used as an anti-corrosion coating, $\mathrm{CO}_{2}$ as reactive gases utilized MIG welding, in swimming pools for $\mathrm{pH}$ recuperation.

$\mathrm{CO}_{2}$ tracking throughout and after the injection of carbon dioxide ought to be performed to make sure that the injected fluid is getting into the storage/garage site and remained cramped. Time-lapse (4-D) seismic measurements, Gravimetry might, Geochemical tracking strategies the use of non-reactive and reactive tracers are used to display the traits of $\mathrm{CO}_{2}$. If the above concerns can be addressed, CCS plays a major role as a remediation method for carbon emission. 
Sustainability, Agri, Food and Environmental Research, (ISSN: 0719-3726), 10(X), 2022: http://dx.doi.org/

\section{CARBON ABATEMENT TECHNOLOGY}

Carbon abatement technology or carbon capture and storage is a process by which carbon dioxide from the power plant is captured, that's compressed, and load into underground geological formations for a safe, secure, and everlasting garage. This means that they can be a part of the answer to weather change, at the same time it can be a primary contribution to the safety and energy supply, and it have the capacity to lessen carbon emissions from fossil fuel power stations by up to $90 \%$ and feature significant export capacity.

\section{CARBON CAPTURE}

Direct air capture (DAT): - It is the manner of chemically capturing the carbon dioxide from the polluted atmospheric air. It is comparably easy to measure and account for the climate benefits of direct air capture, and its viable scale of distribution is expansive. Many groups have already commenced and advanced running direct air capture/seize systems.

Seizing $\mathrm{CO}_{2}$ from air

A Solution of $\mathrm{NaOH}+\mathrm{CO}_{2} \longrightarrow \mathrm{Na}_{2} \mathrm{CO}_{3}$

$\mathrm{Na}_{2} \mathrm{CO}_{3}+\mathrm{Ca}(\mathrm{OH})_{2} \longrightarrow \mathrm{CaCO}_{3}$ crystals

$\mathrm{CaCO}_{3}$ crystals heated $\longrightarrow \mathrm{CaO}$ (hydrated to regenerate $\left.\mathrm{Ca}(\mathrm{OH})_{2}\right) \& \mathrm{CO}_{2}$

Pre-Combustion: - This capture technique refers to catch $\mathrm{CO}_{2}$ from fossil fuels earlier than combustion is completed. For example, from equation 4, coal is partly oxidized in steam and air beneath excessive temperature and pressure offers synthesis gas, that's an aggregate of hydrogen carbon monoxide and $\mathrm{CO}_{2}$ and different gaseous additives like methane. Then that syngas undergoes the water-gas shift reaction and converts the $\mathrm{CO}$ and water to $\mathrm{H}_{2} \& \mathrm{CO}_{2}$ which generating an $\mathrm{H}_{2}$ and $\mathrm{CO}_{2}$-rich gas mixture. The concentration of $\mathrm{CO}_{2}$ in this $\mathrm{H}_{2} \& \mathrm{CO}_{2}$ gas mixture can range from $15-50 \%$. Then those $\mathrm{CO}_{2}$ can be captured, transported, and saved for an extended period.

$$
\text { Partially oxidizes Water shift reaction }
$$

Fuel $\longrightarrow$ Syngas $\left(\mathrm{H}_{2}, \mathrm{CO}, \mathrm{CO}_{2}\right) \longrightarrow \mathrm{H}_{2} \& \mathrm{CO}_{2} \longrightarrow \mathrm{CO}_{2}$

\section{Stream \&Air}

Due to the big quantity of $\mathrm{CO}_{2}$, the pre-combustion capture is generally more efficient.

Post-combustion: - Capture Process refers to seize/catch carbon dioxide $\left(\mathrm{CO}_{2}\right)$ after the combustion of fuel. In traditional fossil fuel power plants, coal, or natural gas is burned with air to generate heat energy that's transformed into electricity. This capturing method makes use of a chemical solvent to dispose of $\mathrm{CO}_{2}$ from the exhaust gas of conventional power plants (gas or coal) or commercial centers inclusive of cement kilns etc. Equation 5, 
Sustainability, Agri, Food and Environmental Research, (ISSN: 0719-3726), 10(X), 2022: http://dx.doi.org/

Amine solution is the fundamental using solvent for this manner, which binds with $\mathrm{CO}_{2}$, then this aggregate is separated the stability exhaust gas and then heated, which separates the $\mathrm{CO}_{2}$. The solvent is cooled and reused.

$$
\mathrm{CO}_{2} \text { containing flue gas }
$$

Heated

Fuel air $\rightrightarrows$ Combustion $\longrightarrow \mathrm{CO}_{2}$ capture with amine $\longrightarrow \mathrm{CO}_{2}$

Advanced solvent, sorbent, and membrane systems, as nicely as novel concepts that could supply a change for the better discounts in each price and strength sanction as compared to presently available technologies. (Bert Metz et al, 2005)

Oxy-fuel combustion: - It is another essential manner of burning hydrocarbon fuel using pure oxygen surroundings, instead of air. The temperature can be managed via way of when the oxygen is diluted with flue gas. The essential motive of the use of oxy-fuel combustion is to result in flue gas with an excessive mass of $\mathrm{CO}_{2}$ after which, separate or seize the $\mathrm{CO}_{2}$ from the flue gas via way of means of low-temperature dehydration processes. This manner allows to, enhance excessive $\mathrm{CO}_{2}$ purity, and decrease the gas volumes because of multiplied density. (Dennis Y.C. Leung et al, 2014).

\section{TRANSPORT}

Pipeline: -The most convenient and more secure technique for the transportation of $\mathrm{CO}_{2}$ gas is pipeline transport. The Advantages consist of cost-effective as compared to other modes of transportation, the energy required to operate pipelines is much less than that needed to operate other modes of transportation, and usually they are surroundings friendly, reliable, appropriate, and much less tactful to deflation when compared to other modes of transportation. The gaseous $\mathrm{CO}_{2}$ is compressed to a pressure of eight MPa to keep away from corrosion and which additionally allows to boom the density of the $\mathrm{CO}_{2}$ thereby making it simpler and transportation price can be reduced.

Ship: - Another handy mode of transportation is ship transport, within the shape of a pressurized cryogenic liquid via way of means of following the traditional era, as used for the LPG. Transportation of $\mathrm{CO}_{2}$ via ship mode is a more secure and high-quality technique for easy processing of enhanced oil recuperation technique. Shipping lets in resilient transport to different locations for EOR at different times. The delivery alternatives contain low capital expenditure than the pipeline transport alternatives, so they're of lower risk. Transportation of $\mathrm{CO}_{2}$ via the ship is an appealing technique in the case of economics, particularly when transferring for big distances.

Motor Transport: - Another mode of workable options for $\mathrm{CO}_{2}$ is road transport, which can transport carbon dioxide at a temperature of $-20^{\circ} \mathrm{C}$ and $2 \mathrm{MPa}$ pressure, however 
Sustainability, Agri, Food and Environmental Research, (ISSN: 0719-3726), 10(X), 2022: http://dx.doi.org/

they're uneconomical because of small unit of transportation. (Dennis Y.C. Leung et al, 2014).

\section{CARBON STORAGE}

Geological storage: -Trap it in rocks

The technology used for $\mathrm{CO}_{2}$ storage/garage is similar to the ones used for the oil and gas enterprise for an extended period. The Carbon dioxide is injected into the underground, frequently into the porous rocks. It is essential to cover the rock with an overlying layer of impermeable rock from escaping to the air. The carbon dioxide can be trapped in three ways: By hydrodynamic trapping $\mathrm{CO}_{2}$ can be trapped as a gas under low permeability cap rock, by mineral carbonation $\mathrm{CO}_{2}$ reacts with minerals, fluids to form a stable compound (For e.g.: $\mathrm{CO}_{2}$ reacts with calcium to form calcium carbonate a stable compound), By solubility trapping $\mathrm{CO}_{2}$ can be dissolved into liquid or oil. As the injected carbon dioxide moves up through the geological storage site towards the cap rock and a number of it's far left at the back of the pore shape and this mechanism is known as residual storage. Geophysical site characterization studies should be done to avoid earthquake prone area for $\mathrm{CO}_{2}$ storage.

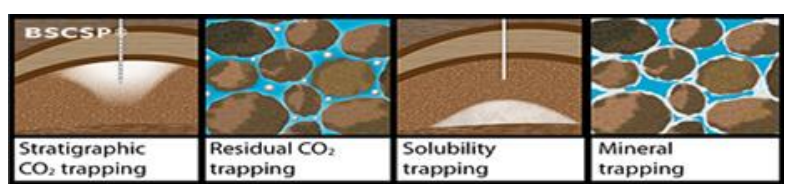

Fig 1: Different trapping mechanisms with increasing storage security over time

(Source: http://www.bigskyCO2.org/node/127)

Trap it in the ocean: - Ocean storage can be done in three methods: - Pipe receive a stream of $\mathrm{CO}_{2} \&$ then direct it offshore for long-term storage. By ship method- using a long hose or pipe promoting rapid diffusion of the $\mathrm{CO}_{2}$ into seawater, Stationary vessel or platform to inject $\mathrm{CO}_{2}$ to a fixed location at or near the ocean bottom. At deep the ocean pressure is high, $\mathrm{CO}_{2}$ is converted to solid $\mathrm{CO}_{2} \&$ sinks slowly to the seafloor \& forms an underwater pool. More researches and studies are still going on related to ocean storage. ( Ofe' lia de Queiroz Fernandes Arau' jo and Jose'Luiz de Medeiros, 2017)

\section{$\mathrm{CO}_{2}$ UTILISATIONS}

Direct utilization: Many industries use $\mathrm{CO}_{2}$ directly, which incorporates the food and drinks enterprise usually used as a preservative, packaging gas, and as a solvent for the extraction of flavors, etc. $\mathrm{CO}_{2}$ can be used as a breathing stimulant in the pharmaceutical enterprise or can act as an intermediate in the synthesis of drugs. (Payal.B.Joshi, 2004)

Enhanced oil and coal bed methane recovery: $\mathrm{CO}_{2}$ used to extract crude oil from an oil field or natural gas from coal deposits which are not minable and additionally facilitates to do away with the oil is trapped in the rocks. Enhanced oil recovery technique can extract 
Sustainability, Agri, Food and Environmental Research, (ISSN: 0719-3726), 10(X), 2022: http://dx.doi.org/

$30-60 \%$ extra of the crude originally available in the well, as compared to primary and secondary extraction which recover $20-40 \%$. Because of the low price and huge availability $\mathrm{CO}_{2}$ is mostly using gas for this mechanism. Under the supercritical situations $\mathrm{CO}_{2}$ is injected below and it mixes nicely with the oil to lower its viscosity, thus assisting to boom the extraction yields. ( Azeem Ghani et al, 2014)

Concrete manufacturing: -For concrete production, cement and sand mix is hardened and cured via way of means of specifically the usage of $\mathrm{CO}_{2}$ rather than water. And following these technology facilitates to lessen carbon dioxide emissions as $70 \%$ by recycling and additionally, it facilitates to keep away from using water within inside the concrete making procedure and can be referred to as "waste $\mathrm{CO}_{2}$ " into grey blocks of concrete. The concrete with $\mathrm{CO}_{2}$ technology facilitates to show carbon dioxide into carbon concrete products with a far decrease carbon footprint.

\section{NOVEL MATERIALS}

Carbon nanotubes: -Fig. 2 indicates carbon nanotubes are tubes that can be crafted from carbon, it is a procedure of changing carbon dioxide $\left(\mathrm{CO}_{2}\right)$ into carbon threads. The threads are nanofibers, and they'll be the constructing blocks of the future. (Geoffrey $\mathrm{S}$. Simate et al, 2010)

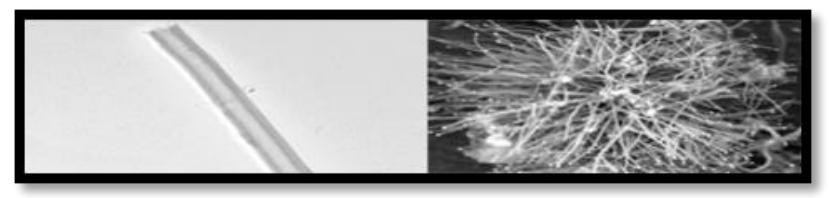

Fig 2: Carbon nanotube from carbon dioxide, 2016, Stuart Licht, lead scientist on a George Washington

Carbon nanofibers are better to metallic in energy, flexibility and are used for plenty of applications like electronics to make lightweight, high-substances utilized in buildings, batteries, aircraft, and athletic equipment. In the car enterprise, they have got already tested to use carbon fiber as steel to lessen the burden of the vehicle. Another area of making use of carbon fiber is bridge construction. The major motive for utility of carbon fiber reinforced plastic become to offer bridge weight loss and economic system of lifting equipment. (Hilal El-Hassan and YixinShao, 2014)

$\mathrm{CO}_{2}$ to carbon nanofibers: - Carbon dioxide can be captured from the vicinity in which carbon emission is excessive. Solar electricity offers the sizeable warmness and energy that is required to interrupt down the $\mathrm{CO}_{2}$ in a molten carbonate bath. The $\mathrm{CO}_{2}$ gets dissolves with electrified electrodes, then the carbon nanofibers which accumulates on the steel electron. Because of the load-bearing capacity, and low weight the carbon fiber can be used as the most suitable material to replace steel and aluminum inside the construction enterprise for retro-fitment projects. The carbon fiber incorporates skinny filaments of 
Sustainability, Agri, Food and Environmental Research, (ISSN: 0719-3726), 10(X), 2022: http://dx.doi.org/

carbon atoms that are bonded collectively with plastic polymer resin with the assist of warmness. The carbon fibers additionally encompass properties like excessive stiffness, excessive tensile strength, low weight, excessive chemical resistance, excessivetemperature tolerance, and low thermal expansion. It has an average longitudinal tensile strength of $2000 \mathrm{MPa} 1$, with an elastic modulus of 150-two hundred GPa2 and, on average, is around 2.5 times stiffer than aluminum.

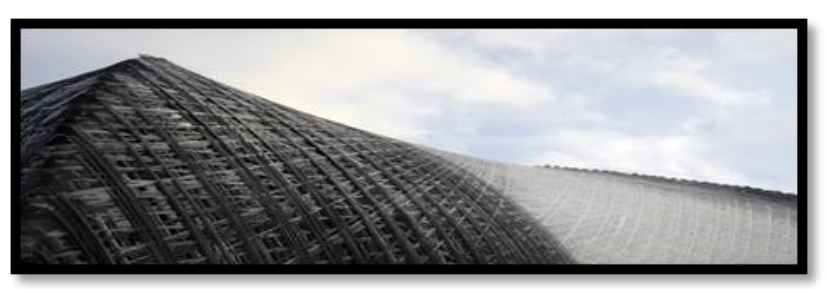

Fig 3: Use of carbon fiber in the construction industry (Source: www.3mb.asia)

Graphene:-It is a 2D shape of carbon, due to its electrical properties, it reveals a new manner for the electronic enterprise. The greenhouse gases like carbon dioxide, collectively with hydrogen gas which converts without delay into graphene with the assist of specifically organized catalytically active metallic surfaces, which well-known shows the ratio of copper and palladium. Graphene has a great application in the electronic in addition to within inside the construction industry, shows in fig 3 , it is able to use for quicker DNA sequencing, flexible displays, etc. (Amartya Chakrabarti et al, 2011)

Green minerals: -Concrete, plastic, paper are the three by-products of green minerals in which $\mathrm{CO}_{2}$ is captured and saved in substances using a process referred to as mineralization. $\mathrm{CO}_{2}$ is performed as a raw material that reacts with olivine, which is a rockforming mineral that binds $\mathrm{CO}_{2}$. The olivine rock (Green mineral) after crushing, the ground olivine is obtained, which then reacts with $\mathrm{CO}_{2}$ to generate $\mathrm{CO}_{2}$ additives, which can be used within inside the manufacturing of concrete paper, polymers. ( Shuxian Ye et al, 2019).

Algae oil: - Algae oil has the advantage of manufacturing bio-oils or lipids. Supercritical carbon dioxide is a clean and green technology that is used to extract those oils from algae (Nannochloropsissalina) for biofuel manufacturing and excessive-value coproducts development. The carbon fibers made out of algae are exact to the fibers that are presently in use within the industry. ( Sara P.Cuellar-Bermudez et al, 2014)

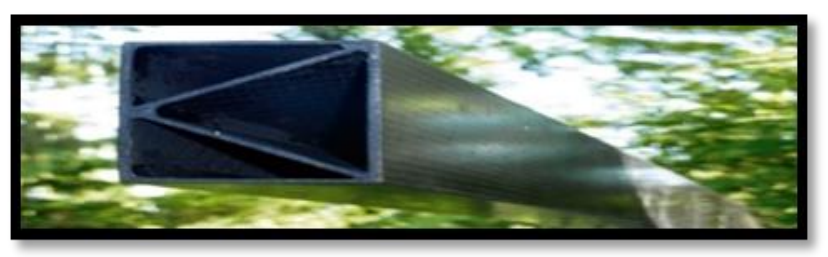


Sustainability, Agri, Food and Environmental Research, (ISSN: 0719-3726), 10(X), 2022: http://dx.doi.org/

Fig 4: A beam made of carbon fiber reinforced granite (Source: www.ribaj.com) The purpose of "Green Carbon" technology to manufacturing carbon-based light-weight construction materials based on algae which can be applied inside the aviation and automotive enterprise

Dry ice pellets to take away paints: - Dry ice is made via way means of liquefying $\mathrm{CO}_{2} \&$ then injected it into a tank\& freezes at a temperature of $109^{\circ} \mathrm{F}$, then it is compressed into solid ice, relying upon whether or not it is created in a pelletizer or block press it can be made into pellets. Dry Ice blasting can act as a surface-friendly elimination tool to take away paint, mold, dust, and a lot of different impurities to any surface without harming the overseas substances. (Lauren R. Millman and James W. Giancaspro, 2012)

\section{$\mathrm{CO}_{2}$ TRACKING FOR SAFETY}

It is essential to screen the $\mathrm{CO}_{2}$ all through capturing, transportation, including before and after the injection in an appropriate garage area, and make sure that injected fluid is migrating into the garage site and reminded restricted. Downhole pressure inside the injection wells is likewise used to tune the reservoir models and expect the most injection rate in conjunction with the garage capacity. Time-lapse (4-D) seismic measurements emerged to be a well-based method inside the offshore industrial-scale initiatives of Sleipner and Snohvit, for the assessment of $\mathrm{CO}_{2}$ plume relocation. The gravimetry technique would possibly assist to present reassuring information on $\mathrm{CO}_{2}$ insitu density and dissolution rates within the shape of water if seismic statistics cannot be received because of budget limitations. Geochemical tracking techniques using nonreactive and reactive tracers are a terrific method to quantitatively mark the physical and geochemical modifications at the sector scale. (A. Brown et al, 2017, Nur Fatma Fadilah Yaacob et al, 2020).

\section{ADVANTAGES}

The main purpose of $\mathrm{CO}_{2}$ is; it can be utilized in MIG welding as a reactive gas. Carbon Dioxide technology for swimming pools $\mathrm{pH}$ manipulate is a secure manner to keep $\mathrm{pH}$ tiers in swimming pools and can also gain advanced water quality. When $\mathrm{CO}_{2}$ dissolves in swimming pools there forms a moderate and carbonic acid, which works as equal as the uses of mineral acid plus it forms a natural bicarbonate buffer which allows stabilizing the $\mathrm{pH}$ levels/tiers in a pool. $\mathrm{CO}_{2}$ is being utilized in softening water to keep away from corrosion problems, $\mathrm{CO}_{2}$ gas is used to harden the mass of sand after the mold has been made. (M. Venkata Ramana, 2016,Lu Shanping et al, 2005) 
Sustainability, Agri, Food and Environmental Research, (ISSN: 0719-3726), 10(X), 2022: http://dx.doi.org/

\section{LIMITATIONS}

$\mathrm{CO}_{2}$ contains moisture content is very corrosive for the pipeline, so it is important to be craft the pipeline from a corrosion-resistant alloy. Leakage ought to arise through undetected faults and fractures or via leaking wells in which launch to the floor is extra slow and diffuse. so this sort of launch is probable to be detected fast and stopped by the usage of strategies which are to be had today. Assessing public notion of CCS is hard due to the highly technical and far-flung nature of this trouble at the existing time and high capital and running price for modern-day sorption.

\section{CONCLUSION}

The paper gives an extensive evaluation of the current literature about carbon seize and garage and using $\mathrm{CO}_{2}$ for creation purposes. The major final results and factor of view may be summarized as:

This paper has reviewed diverse technology associated with $\mathrm{CO}_{2}$ seize, separation, transport, storage, and tracking and the sizable possibilities within inside the construction enterprise by recycling $\mathrm{CO}_{2}$, thereby $\mathrm{CCS}$ is now visible as an interpretative part of the world's future low-carbon energy portfolio. The research is on-going on the utilization of $\mathrm{CO}_{2}$ in organic chemical polymer and plastic production and also aims for the elimination of chemical intermediates and therefore the elimination of toxic wastes, instead of the storage of $\mathrm{CO}_{2}$. This extensive evaluation advances the current understanding of research development on carbon capture and storage for the future of the construction industry and provides treasured steering for the research precedence in the future.

\section{REFERENCES}

A. Brown, C. Eickhoff, J.E.A. Reinders, I.Raben, M.Spruijt, F.Neele,(2017),IMPACTS: Framework for Risk Assessment of $\mathrm{CO} 2$ Transport and Storage Infrastructure, Energy Procedia Volume 114, Pages 6501-6513

Amartya Chakrabarti, Jun Lu, Jennifer C. Skrabutenas, Tao Xu, Zhili Xiao, John A. Maguire and Narayan S. Hosmane,(2011),Conversion of carbon dioxide to few-layer graphene", Journal of Materials Chemistry 21(26):9491-9493

Arshad Raza, Raoof Gholami, Reza Rezaee, Vamegh Rasouli, Minou Rabiei, (2018), Significant aspects of carbon capture and storage - A review, Petroleum, Volume 5, Issue 4, Pages 335-340.

Azeem Ghani, Faisal Khan \& Vikram Garaniya, (2014), Improved oil recovery using CO2 as an injection medium: a detailed analysis, Journal of Petroleum Exploration and Production Technology volume 5, pages 241-254.

Bert Metz, Ogunlade Davidson, Heleen de Coninck, Manuela Loos, Leo Meyer, (2005), Carbon Dioxide Capture and Storage, Intergovernmental Panel on Climate Change. 
Sustainability, Agri, Food and Environmental Research, (ISSN: 0719-3726), 10(X), 2022:

http://dx.doi.org/

Dennis Y.C. Leung, Giorgio Caramanna, M. Mercedes Maroto-Valer, (2014),An overview of current status of carbon dioxide capture and storage technologies, Renewable and Sustainable Energy Reviews, Volume 39, Pages 426-443

Geoffrey S. Simate, Sunny E. Iyuke, SehliseloNdlovu, Clarence S. Yah, Lubinda F. Walubita, (2010), The production of carbon nanotubes from carbon dioxide: challenges and opportunities", Journal of Natural Gas Chemistry 19, pages 453460.

Hilal El-Hassan and YixinShao, (2014) Carbon Storage through Concrete Block Carbonation Curing, Journal of Clean Energy Technologies, Vol. 2, No. 3.

J.C.Blackford, R.Torres, P.Cazanave, Y.Artioli,(2013),Modelling Dispersion of CO2 Plumes in Sea Water as an Aid to Monitoring and Understanding Ecological Impact, Energy Procedia, Volume 37, Pages 3379-3386.

Lu Shanping, FujiiHidetoshi, NogiKiyoshi, (2005), Effects of CO2 shielding gas additions and welding speed on GTA weld shape, Journal of Materials Science 40(9):24812485.

Lauren R. Millman, James W. Giancaspro, (2012), Environmental Evaluation of Abrasive Blasting with Sand, Water, and Dry Ice, International Journal of Architecture, Engineering and Construction Vol 1, No 3, pp. 174-182.

M. VenkataRamana, (2016), Parametric Optimisation of Carbon - Dioxide Moulding

Process for Maximum Mold Hardness, International Journal of Engineering

Research \& Technology (IJERT) Vol. 5 Issue 01

Nur Fatma Fadilah Yaacob, Muhamad Razuhanafi Mat Yazid, Khairul Nizam Abdul Maulud, Noor Ezlin Ahmad Basri, (2020), A Review of the Measurement Method, Analysis, and Implementation Policy of Carbon Dioxide Emission from Transportation, Sustainability 12(14):5873.

Ofe' lia de Queiroz Fernandes Arau' jo and Jose'Luiz de Medeiros, (2017), Carbon capture and storage technologies: present scenario and drivers of innovation, Current Opinion in Chemical Vol 17, Pages 22-34.

Payal.B.Joshi,(2014), Carbon dioxide utilisation: A comprehensive review, Int. J. Chem. Sci.: 12(4), 1208-1220,2014

Rosa M.Cuéllar-Franca, Adisa Azapagic, (2014),Carbon capture, storage and utilisation technologies: A critical analysis and comparison of their life cycle environmental impacts, Journal of $\mathrm{CO}_{2}$ Utilization Volume 9, Pages 82-102.

Sean Monkman, Mark MacDonald, (2017), On carbon dioxide utilization as a means to improve the sustainability of ready-mixed concrete, Journal of Cleaner Production, pages365-375. 
Sustainability, Agri, Food and Environmental Research, (ISSN: 0719-3726), 10(X), 2022 :

http://dx.doi.org/

Shuxian Ye, Shuanjin Wang, Limiao Lin, Min Xiao, Yuezhong Meng, (2019), CO2 derived biodegradable polycarbonates: Synthesis, modification and applications, Advanced Industrial and Engineering Polymer Research Volume 2, Issue 4, Pages 143-160.

Sara P.Cuellar-Bermudez, Jonathan S.Garcia-Perez, Bruce E. Rittmann, Roberto ParraSaldivar,(2014), Photosynthetic bioenergy utilizing $\mathrm{CO}_{2}$ : an approach on flue gases utilization for third generation biofuels, Journal of Cleaner Production, Volume 98 , Pages 53-65.

Received: $15^{\text {th }}$ February 2021; Accepted: $18^{\text {th }}$ May 2021; First distributed: $18^{\text {th }}$ May 2021. 